\title{
DIET OF THE COLUBRID SNAKE, Thamnodynastes strigatus (GÜNTHER, 1858) FROM PARANÁ STATE, BRAZIL, WITH FIELD NOTES ON ANURAN PREDATION
}

\author{
BERNARDE, P. S., ${ }^{1}$ MOURA-LEITE, J. C. ${ }^{2,3}$ MACHADO, R. A. ${ }^{2}$ and \\ KOKOBUM, M. N. C. ${ }^{4}$ \\ ${ }^{2}$ Departamento de Zoologia, Universidade Federal do Paraná, Curso de Pós-graduação em Zoologia, C.P. 19020, \\ CEP 81531-990, Curitiba, Paraná, Brazil \\ ${ }^{3}$ Museu de História Natural, Capão da Imbuia, Departamento de Zoológico, SMMA, Prefeitura Municipal de \\ Curitiba, Rua Prof. Benedito Conceição, 407, CEP 82810-080, Curitiba, Paraná, Brazil \\ ${ }^{4}$ Departamento de Biociências, Curso de Pós-graduação em Ecologia e Conservação de Recursos Naturais, \\ Universidade Federal de Uberlândia, C.P. 593, CEP 38400-902, Uberlândia, Minas Gerais, Brazil \\ Correspondence to: Paulo S. Bernarde, ${ }^{1}$ Departamento de Zoologia, Instituto de Biociências, Curso de Pós- \\ graduação em Zoologia, Unesp, C. P. 199, CEP 13506-90, Rio Claro, São Paulo, Brazil, \\ e-mail: bernarde@bol.com.br \\ Received November 24, 1999 - Accepted January 7, 2000 - Distributed November 30, 2000
}

\begin{abstract}
Dissection of 44 specimens of the colubrid snake Thamnodynastes strigatus (Serpentes: Colubridae) provided data on food habits. Prey items include frogs (71.4\% of the sample), rodents (14.3\%), fishes $(10.7 \%)$, and lizards (3.6\%). The most of the anuran species recorded (Bufo sp., Leptodactylus sp., Physalaemus cuvieri and Scinax fuscovarius) are ground dwellers or call at the water level. Field observations provided information on the feeding behavior.
\end{abstract}

Key words: serpentes, Colubridae, Thamnodynastes strigatus, diet, anuran predation.

\section{RESUMO}

Dieta da Serpente Colubridae, Thammodynastesstrigatus (Günther, 1858), no Estado do Paraná, Brasil, com notas de predação sobre anuros na natureza

São apresentados dados da dieta de Thamnodynastes strigatus (Serpentes: Colubridae), a partir da dissecção de 44 espécimes. No tubo digestivo dos exemplares examinados foram encontrados anfíbios anuros (71,4\% da amostra), roedores (14,3\%), peixes (10,7\%) e lagartos (3,6\%). A maioria das espécies de anuros (Bufo sp., Leptodactylus sp., Physalaemus cuvieri e Scinax fuscovarius) encontradas no exame de conteúdo estomacal de T. strigatus, utiliza o solo ou o nível d'água como sítio de vocalização. Também são apresentados dados sobre a observação de eventos de predação na natureza.

Palavras-chave: serpentes, Colubridae, Thamnodynastes strigatus, dieta, predação de anuros.

\section{INTRODUCTION}

The colubrid genus Thamnodynastes, Wagler, 1830, occurs in South America (Peters \& OrejasMiranda, 1970). Identification of the species of that genus is problematical, since this group deserves a taxonomic revision (Vanzolini, 1986). The available data from Thamnodynastes species diets are scarce and controversial (e.g., Schupp, 1913;
Serié, 1919; Amaral, 1924; Vanzolini, 1948; Amaral, 1978; Gallardo, 1977; Vanzolini et al., 1980; Lema et al., 1983, Strüssmann \& Sazima, 1993; Yanosky et al., 1996; Rocha \& Vrcibradic, 1998).

Encounters of snakes in the nature are casual and visualization of these animals in predatory activity is rare (Mushinsky, 1987; Sazima, 1989). Thus, there are very little information about food habits or predation events based on naturalistic 
observations (e.g., Sazima \& Martins, 1990; Strüssmann \& Sazima, 1990; Martins et al., 1993). Alternative ways to approach this kind of study are dissecting the digestive trait from collection specimens and observing the feeding behaviour of captive snakes (e.g., Marques \& Puorto, 1994, 1998; Marques \& Sazima, 1997; Prudente et al., 1998).

In this paper, we present informations about diet and field notes on anuran predation by the colubrid snake, Thamnodynastes strigatus (Günther, 1858) from Paraná State, Brazil.

\section{MATERIAL AND METHODS}

We have dissected digestive traits of 44 specimens of Thamnodynastes strigatus from Paraná State, Brazil, housed in the herpetological collections of Museu de História Natural Capão da Imbuia (MHNCI), Curitiba, and Universidade Estadual de Londrina (MZUEL). A medioventral incision was made to exposed the stomach and the anterior third of the gut, was sectioned longitudinally. Stomach and gut contents were fixed in a $10 \%$ formalin solution. Prey items were recorded and, whenever as possible, their snout-vent length (SVL) measured or estimated.

Two occasional naturalistic observations, in the course of an anuran community study (Bernarde, 1999), were made at a permanent pond ( $40 \times 12 \mathrm{~m})$ at the edge of the forest, in the Parque Estadual Mata dos Godoy, Londrina municipality, Paraná State, and have furnished informations about diet and predatory behaviour. Moreover a specimen was captured occasionally in the Parque Ecológico da Klabin, Telêmaco Borba municipality, Paraná State.

All the snake sample is morphologically homogeneous and corresponds well to the diagnosis of Günther (1858) in the original description of Thamnodynastes strigatus.

Specimens examined in Paraná: Barbosa Ferraz (MHNCI 3288); Bituruna (MHNCI 1252); Curitiba (MHNCI 1537); Dois Vizinhos (MHNCI 3393); Londrina (MZUEL 040, 065, 124, 599, 601, 700, 1001, 1245, 1261, 1262); Manoel Ribas (MHNCI 3248); Pinhão (MHNCI 5029); São José dos Pinhais (MHNCI 3788); Terra Rica (MHNCI 695).

\section{RESULTS}

Information about prey items is summarized in Table 1. From the total sample examined, 18 specimens $(41 \%)$ presented 28 prey items. Anurans predominate $(71 \%)$, followed by rodents $(14 \%)$, fishes $(11 \%)$, and lizards (4\%). Most of anurans recorded belongs to the family Hylidae (78\%), following the families Leptodactylidae (17\%) and Bufonidae (5\%).

Most of the snakes (83\%) presented only one prey item. One specimen (MZUEL 601) had seven adult individuals of Scinax fuscovarius (Hylidae) in similar stage of digestion and possibly were predated in the same day. Two other specimens presented three items: MZUEL 599 showed three adult anurans (one Physalaemus cuvieri, Leptodactylidae and two $S$. fuscovarius, Hylidae).

A young specimen (MZUEL 124, $15 \mathrm{~cm}$ SVL) has ingested three fishes (Poecilia sp., Poeciliidae).

An adult male (ca. $70 \mathrm{~cm} \mathrm{SVL}$ ) was observed (by PSB) at night $(20: 00 \mathrm{~h})$ in a permanent pond, ingesting an adult Bufo crucifer (Bufonidae; ca. $8 \mathrm{~cm} \mathrm{SVL}$ ). The ingestion of the anuran was performed head first, and took about ten minutes.

Envenomation must be utilized in the subjugation since, despite its free limbs, the prey remained in complete immobility during the process. In other event in this same pond, the same specimen was observed (by PSB \& MNCK) attacking 12 time one hylid imago and 11 males of Hyla minuta (Hylidae), calling on aquatic plants (Pistia, Araceae).

Only five anurans were predated (success of $42 \%$ ). In the same night, more of 50 males of $H$. minuta were calling with frequent agonistic interactions and presence of sattelite males (Cardoso \& Haddad, 1984; Haddad, 1992).

As long as the snake approaches, the anurans remained immobile and stopped the call, sometimes by ca. 20 minutes.

The snake perception of the H. minuta males was apparently visual, at a maximum distance of $50 \mathrm{~cm}$, while these males vocalizated, expanding the body laterally and the vocal sac into the visual field of the predator, or moving toward other males during territorial confrontation. Sattelite males, males calling away or those that ceased the vocalization were not reached. One silent specimen, $8 \mathrm{~cm}$ far from the snake was not attacked. At this time interval, the snake was motionless during 20 minutes with the head facing an adult male of $H$. faber, at a distance of $10 \mathrm{~cm}$, also motionless and partially submerged between aquatic plants. 
TABLE 1

Prey items from gut contents of Thamnodynastes strigatus in Paraná State Brazil. The number of prey items (n) of a certain type is provided with prey frequency in parentheses.

\begin{tabular}{|c|c|c|}
\hline Prey type & $\mathbf{n}$ & $(\%)$ \\
\hline \multicolumn{3}{|l|}{ Osteichthyes } \\
\hline \multicolumn{3}{|l|}{ Poeciliidae } \\
\hline Poecilia sp. & 3 & 10.7 \\
\hline \multicolumn{3}{|l|}{ Anura } \\
\hline \multicolumn{3}{|l|}{ Bufonidae } \\
\hline Bufo sp. & 1 & 3.6 \\
\hline \multicolumn{3}{|l|}{ Hylidae } \\
\hline Scinax fuscovarius & 10 & 35.8 \\
\hline Scinax sp. & 2 & 7.1 \\
\hline Unidentified hylids & 2 & 3.6 \\
\hline \multicolumn{3}{|l|}{ Leptodactylidae } \\
\hline Leptodactylus sp. & 1 & 3.6 \\
\hline Physalaemus cuvieri & 2 & 7.1 \\
\hline Unidentified anurans & 2 & 7.1 \\
\hline \multicolumn{3}{|l|}{ Lacertilia } \\
\hline \multicolumn{3}{|l|}{ Gekkonidae } \\
\hline Hemidactylus mabouia & 1 & 3.6 \\
\hline \multicolumn{3}{|l|}{ Rodentia } \\
\hline Unidentified rodents & 4 & 14.4 \\
\hline
\end{tabular}

When the snake moved away, the anuran moved for ca. $1 \mathrm{~m}$, climbing a "taboa" plant (Typha sp., Typhaceae) $40 \mathrm{~cm}$ high. This individual was bleeding, whith one leg injured. Approximately two hours later, the snake located drops of blood on a fallen leave at the water level, under the anuran. Elevating the anterior third of the body, the snake started an exploration of the plant; at this moment, the anuran moved to another plant $50 \mathrm{~cm}$ away.

Approximately 20 minutes later, the snake located the plant occupied by the anuran. Soon after, returned to examine the first plant and, at this time, the anuran moved away.

An adult specimen captured (by RAM) at morning (9:00 h) near a pond, it regurgitated two adult individuals of Physalaemus cuvieri (Leptodactylidae) and Scinax perereca (Hylidae).

\section{DISCUSSION}

Thamnodynastes strigatus may be considered a anuran-eating snake that may include other items in its diet (rodents, fishes, and lizards). Some authors (e.g., Vanzolini, 1948; Lema et al., 1983; Strüssmann \& Sazima, 1993; Yanosky et al., 1996; Rocha \& Vrcibradic, 1998) mentioned anurophagy in some species of the genus Thamnodynastes. The occurrence of other items in the diets, like fishes, lizards, lizard eggs, rodents and also canibalism were mentioned elsewhere (Amaral, 1924, 1978; Lema et al., 1983; Rocha \& Vrcibradic, 1998; Vanzolini et al., 1980). These data may be interpreted as occasional items or geographic differences in the diet of some species of the genus.

All preys (anurans, rodents, and a gekkonid lizard) recorded in this study present predominantly nocturnal activity, exception made to the poeciliid fishes. This foraging pattern is quite different to that recorded for an other predominantly nocturnal species of snakes (e.g., Rhinobothrium lentiginosum and Siphlophis spp.), that prey diurnal animals resting at night (Oliveira \& Martins, 1998; Prudente et al., 1998). This is similar to the pattern known for Leptodeira anullata, a predator of noc- 
turnal anurans (Vitt,1996). Despite its high toxicity, presence of species of the genus Bufo in the diet of neotropical colubrids is recorded for some species, particularly for the Tribe Xenodontini (Gudynas, 1979; Vitt, 1983; Michaud \& Dixon, 1989). These are the first records of bufophagy for the genus Thamnodynastes.

Thamnodynastes strigatus is an opistoglyph snake. Subjugation by envenomation is generally related to dangerous preys (Greene, 1976; Marques \& Puorto, 1994; Andrade \& Silvano, 1996). Most of anuran species may not considered dangerous preys but can show defensive tactics that hinders snake ingestion, like body inflation and holding snake head with the paws (e.g., Dvellman \& Trueb, 1986; Martins, 1990; Azevedo-Ramos, 1995). Thus, envenomation can help subjugation of anurans by impeding prey movements and so facilitating prey ingestion. Envenomation can also help subjugation of rodents which may be considered potentially dangerous. Some species that eat dangerous preys when adult (e.g., rodents and snakes), prey anurans or lizards when young. This fact may be correlated either to reduced risk of injury or to lower availability of dangerous preys at adequate size (Sazima \& Martins, 1990; Marques \& Puorto, 1994; Andrade \& Silvano, 1996). Presence of rodents in this study was detected only in larger individuals (SVL $=360 \mathrm{~mm}$ or more). Possibly rodents are not components of the diet of the juveniles, due to its size and risk of injury involved.

Only three young specimens composed the sample. One of these specimens ingested small fishes and the other two, anurans. Probably other small, locally abundant anuran species (like Hyla minuta, H. nana and Physalaemus cuvieri) may be a significant part of the diet of juvenile specimens of T. strigatus. However, this hypothesis is not confirmed.

Most of the anuran species of the study area used as food by T. strigatus call on the ground or at the level of water (Bernarde, 1999), indicating that this snake forages mostly in these conditions (Bernarde et al., in press). The occurrence of arboreal species (hylids and one gekkonid) and fishes as prey suggests that foraging may occur also off the ground (on tree leaves and under water). Anurans that occupies the ground or the level of water (floating, partially submerged or onto aquatic plants) as calling site are apparently more susceptible to predation by $T$. strigatus.
Satellite males and probably females of Hyla minuta suffer minor rate of predation by $T$. strigatus than calling males. During agonistic interactions, males are apparently more susceptible to snake predation.

The same condition is presumed to other syntopic species, like Hyla faber and H. nana, that also present combat interactions during the reproductive season (Martins et al., 1998; PSB, pers. obs.). Haddad \& Bastos (1997) suggest that males of Bufo crucifer are more exposed to predators like water bugs (Bellostomatidae) and fishes (Hoplias malabaricus) during active search of females. This may be true in relation to $T$. strigatus, that apparently search for moving preys.

Natural history studies with Hyla faber and Phyllomedusa distincta (Martins et al., 1993; Castanho, 1996) in Southeastern Brazil demonstrate the role of snakes as important predators of adult anurans. This study shows the same condition to H. minuta, Physalaemus cuvieri, and Scinax fuscovarius, so that: 1) one specimen contained seven adult individuals of $S$. fuscovarius in its stomach; 2) five adult males of $H$. minuta were predated in about five hours of foraging by only one snake; and 3) seven snakes of this species were observed in the same pond.

Aknowledgments - We are indebted to Célio F. B. Haddad, Emygdio L. A. de Monteiro Filho, Márcio R. C. Martins, and Otávio A. V. Marques for very important suggestions and for carefully read the manuscript; to Walter P. Boeger for the revision of the english version; to CAPES fellowships to PSB; and CNPq fellowships to RAM and MNCK (Grant 132465/2000-0).

\section{REFERENCES}

AMARAL, A., 1924, Contribuição à biologia dos ophidios brasileiros (habitat, hábitos e alimentação). 1a Nota prévia. Coll. Trab. Inst. Butantan, 2: 177-181.

AMARAL, A., 1978, Serpentes do Brasil. Iconografia Colorida. 2 ed., Editora Melhoramentos/Editora da Universidade de São Paulo, 247p.

ANDRADE, R. O. \& SILVANO, R. A., 1996, Dieta e comportamento alimentar da "falsa-coral" Oxyrhopus guibei Hoge \& Romano (Serpentes, Colubridae). Revta. Bras. Zool., 13: 143-150.

AZEVEDO-RAMOS, C., 1995, Defense behaviors of the Neotropical treefrog Hyla geographica (Anura, Hylidae). Rev. Brasil. Biol., 55: 45-47.

BERNARDE, P. S., 1999, Aspectos da biologia e ecologia da anurofauna no Município de Londrina, Estado do Paraná, Brasil (Amphibia: Anura). Dissertação de Mestrado, Setor de Ciências Biológicas da Universidade Federal do Paraná, 75p. 
BERNARDE, P. S., KOKUBUM, M. N. C. \& MARQUES, in press, Utilização de habitat e atividade em Thammodynastes strigatus (Günther, 1858), no sul do Brasil (Serpentes, colubridae). Bol. Mus. Nac. Rio de Janeiro, 428.

CARDOSO, A. J. \& HADDAD, C. F. B., 1984, Variabilidade acústica em diferentes populações e interações agressivas de Hyla minuta (Amphibia, Anura). Ciênc. Cult., 36 : 1.393-1.399.

CASTANHO, L. M., 1996, Phyllomedusa distincta (leaffrog). Predation. Herpetol. Rev., 27: 141.

DUELLMAN, W. E. \& TRUEB, L., 1986, Biology of amphibians. McGraw-Hill Book Company, New York, 670p.

GALlARDO, J. M., 1977, Reptiles de los alrededores de Buenos Aires. EUDEBA, Buenos Aires, 273p.

GREENE, H. W., 1976, Scale overlap as a directional sign stimulus for ingestion by ophiophagous snakes. $Z$. Tierpsychol., 41: 113-120.

GUDYNAS, E., 1979, Notes on the ecology of Lystropis (sic) dorbignyi in Uruguay. ASRA Journal, 1: 24-33.

GÜNTHER, A., 1858, Catalogue of Colubrine Snakes in the collection of the British Museum. Trustees of British Museum, London, 281p.

HADDAD, C. F. B., 1992, Satellite behavior in the neotropical treefrog, Hyla minuta (Anura: Hylidae). J. Herpetol., 25: 226-229.

HADDAD, C. F. B. \& BASTOS, R. P., 1997, Predation on the toad Bufo crucifer during reproduction (Anura: Bufonidae). Amphibia-Reptilia, 18: 295-298.

LEMA, T., ARAúJO, M. \& AZEVEDO, A., 1983, Contribuição ao conhecimento da alimentação e do modo alimentar de serpentes do Brasil. Com. Mus. Ciênc., PUC$R S, 26: 41-121$.

MARQUES, O. A. V. \& PUORTO, G., 1994, Dieta e comportamento alimentar de Erythrolamprus aesculapii, uma serpente ofiófaga. Rev. Brasil. Biol., 54: 253-259.

MARQUES, O. A. V. \& PUORTO, G., 1998, Feeding, reproduction and growth in the crowned snake Tantilla melanocephala (Colubridae), from southeastern Brazil. Amphibia-Reptilia, 19: 311-318.

MARQUES, O. A. V. \& SAZIMA, I., 1997, Diet and feeding behaviour of the coral snake, Micrurus corallinus, from the Atlantic Forest of Brazil. Herp. Nat. Hist., 5: 88-93.

MARTINS, M., 1990, História natural do sapo ferreiro (Hyla faber Wied) na região de Campinas, Estado de São Paulo. Dissertação de Mestrado, Instituto de Biociências da Universidade Estadual de Campinas, 140p.

MARTINS, M., POMBAL JR., J. P. \& HADDAD, C. F. B., 1998, Escalated agressive behaviour and facultative parental care in the nest building gladiator frog, Hyla faber. Amphibia-Reptilia, 19: 65-73.

MARTINS, M., SAZIMA, I. \& EGLER, S. G., 1993, Predators of the nest building gladiator frog, Hyla faber, in southeastern Brazil. Amphibia-Reptilia, 14: 307-309.

MICHAUD, E. J. \& DIXON, J. A., 1989, Prey items of 20 species of the Neotropical colubrid snake genus Liophis. Herpetol. Rev., 20: 39-41.
MUSHINSKY, H. R., 1987, Foraging ecology, pp. 302-334. In: R. A. Seigel, J. T. Collins \& S. S. Novak (eds.), Snakes: Ecology and Evolutionary Biology. MacMillan Publ. Co., New York, 529p.

OLIVEIRA, M. E. \& MARTINS, M., 1998, Rhinobothyum lentiginosum (NCN). Diet. Herpetol. Rev., 29: 105.

PETERS, J. A. \& OREJAS-MIRANDA, B., 1970, Catalogue of the Neotropical Squamata. Part I. Snakes. Bull. U. S. Natl. Mus., 297: 1-347.

PRUDENTE, A. L. C., MOURA-LEITE, J. C. \& MORATO, S. A. A., 1998, Alimentação das espécies de Siphlophis Fitzinger (Serpentes, Colubridae, Xenodontinae, Pseudoboini). Revta. Bras. Zool., 15: 375-383.

ROCHA, C. F. D. \& VRCIBRADIC, D., 1998, Reptiles as predators of vertebrates and as preys in a restinga habitat of southeastern Brazil. Ciênc. Cult., 50: 364-368.

SAZIMA, I., 1989, Comportamento Alimentar da Jararaca, Bothrops jararaca: Encontros provocados na natureza. Ciênc. Cult., 41: 500-505.

SAZIMA, I. \& MARTINS, M., 1990, Presas grandes e serpentes jovens: quando os olhos são maiores que a boca. Mem. Inst. Butantan, 52: 73-79.

SCHUPP, A., 1913, As cobras do Rio Grande do Sul. Editora Vozes, Petrópolis, 80p.

SERIÉ, P., 1919, Notas sobre la alimentación de algunos ofídios. Rev. Jardin Zool. Buenos Aires, 15: 305-328.

STRÜSSMANN, C. \& SAZIMA, I., 1990, Esquadrinhar com a cauda: uma tática de caça da serpente Hydrodynastes gygas no Pantanal, Mato Grosso. Mem. Inst. Butantan, 52: $57-61$.

STRÜSSMANN, C. \& SAZIMA, I., 1993, The snake assemblage of the pantanal at Poconé, Western Brazil: faunal composition and ecological summary. Stud. Neotrop. Fauna Environment, 28: 157-168.

VANZOLINI, P. E., 1948, Notas sobre os ofídios e lagartos de Cachoeira das Emas, no município de Pirassununga, Estado de São Paulo. Rev. Brasil. Biol., 8: 377-400.

VANZOLINI, P. E., 1986, Addenda and corrigenda to the Catalogue of Neotropical Squamata. Smiths. Herpetol. Inf. Serv., 70: 1-25.

VANZOLINI, P. E., RAMOS-COSTA, A. M. M. \& VITT, L. J., 1980, Répteis da Caatinga. Acad. Bras. Ciênc., Rio de Janeiro, $161 \mathrm{p}$.

VITT, L. J., 1983, Ecology of an anuran-eating guild of terrestrial tropical snakes. Herpetologica, 39: 52-66.

VITT, L. J., 1996, Ecological observations on the tropical colubrid snake Leptodeira annulata. Herp. Nat. Hist., 4: 69-76.

YANOSKY, A. A., DIXON, J. R. \& MERCOLLI, C., 1996, Ecology of the snake community at El Bagual Ecological Reserve, northeastern Argentina. Herp. Nat. Hist., 4: 97110 